\title{
Por um cristianismo social: a proposta dos cristãos - o semanário Brasil, Urgente (1963-1964)
}

\author{
For a social Christianity: the Christians proposal - \\ the weekly publication Brasil, Urgente (1963-1964)
}

Lucas Aparecido Costa

O jornal Brasil, Urgente foi uma importante publicação que contribuiu para a difusão do ensino social de João XXIII (1958-1963), compendiado em suas encíclicas sociais Mater et Magistra (1961) e Pacem in Terris (1963). Espaço aberto para discussões sobre assuntos variados - não sendo a divulgação do cristianismo sua única intenção -, defendeu também as iniciativas governamentais do país cujo conteúdo expressasse como medida ideal de desenvolvimento a pessoa humana. ${ }^{1}$

Para compreender seu surgimento, sua efêmera duração e seu epílogo, é preciso atentar para alguns pontos fundamentais: 1) Brasil, Urgente fez parte de

Lucas Aparecido Costa é mestre em História pela Universidade Estadual Paulista Júlio de Mesquita Filho e doutorando em História e Cultura Social na Faculdade de Ciências Sociais e Humanas (UNESP, campus de Franca) (prof.lucasaparecido@gmal.com).

Artigo recebido em 30 de dezembro de 2011 e aprovado para publicação em 23 de março de 2012.

Est. Hist., Rio de Faneiro, vol. 25, n 49, p. 190-208, janeiro-junho de 2012. 
um amplo processo em que fiéis católicos de várias capitais, ${ }^{2}$ importantes para as disputas internas ao campo religioso, desviaram seu caminho para uma proposta de modernidade adversa à defendida pela Igreja; ${ }^{3}$ 2) $\mathrm{O}$ semanário sintetizou, em sua breve existência, duas formas de ser da Igreja - Igreja socialmente engajada e Igreja politicamente engajada ou Igreja Popular; ${ }^{4}$ 3) O semanário lutou para se legitimar como veículo de informação representante fiel do cristianismo.

\section{A trajetória do hebdomadário Brasil, Urgente (1963-1964)}

Na origem de projetos alternativos de grande magnitude sempre há, segundo Bernardo Kucinski (1991), um episódio no qual a grande imprensa, por motivos diversos, força um grupo, não especificamente de jornalistas, a propor um veículo de informação alternativo. Esse dado observado pelo autor ilustra bem os fatores imediatos à criação do semanário Brasil, Urgente. O acontecimento que se tornou o estopim para o movimento social Brasil, Urgente propor uma imprensa alternativa se deu quando do episódio da Greve de Perus. Segundo o depoimento de Frei Carlos Josaphat, a grande imprensa veiculou uma informação equivocada sobre o confronto entre policiais e trabalhadores da Perus; nas palavras do frade, essa foi a "gota d'água" para que seu grupo se reunisse e decidisse: "Vamos fundar um jornal, é preciso fundar um jornal!" (Meneses, Cunha Jr., Jensen e Tenório, 2002: 476). O grupo de Josaphat chegava, então, à constatação da necessidade de um veículo de informação defensor e mensageiro da verdade dos fatos, que eram distorcidos pela grande imprensa. O paradigma, no caso, era o jornal francês Témoignage Chrétien, periódico combativo que, a partir da ocupação da França pela Alemanha em 10 de maio de 1940, entrou para clandestinidade.

No julgamento de Frei Carlos, o semanário Brasil, Urgente foi “o primeiro jornal alternativo que tenha circulado num plano amplo. A nossa primeira tiragem foi de 100.000, baixando logo no segundo número para 35.000, e a gente estava marchando para subir para os 100.000 e para a frente" (Meneses, Cunha Jr, Jensen e Tenório, 2002: 476). As matérias de cunho político veiculadas pelo hebdomadário não proporcionavam uma opção que levasse o cidadão de cultura média a deixar de ler o jornal tradicional, por exemplo, O Estado de São Paulo. Mas era alternativo o enfoque reservado às matérias divulgadas pela grande imprensa. Por esse motivo, Brasil, Urgente, como outros jornais, sobretudo os da década subsequente, dependia da grande imprensa em seu intento de proporcionar ao leitor uma outra visão dos acontecimentos. Nesse ponto, concordamos com Perseu Abramo quando de sua afirmação: 
O que se esforçava por ser alternativo era o ângulo da abordagem da matéria, os informantes ouvidos em "off”, a orientação oposicionista da análise e da interpretação, e, naturalmente, o posicionamento ideológico e político diante do assunto tratado, que se refletia nos títulos, nas fotos nas charges e nos editoriais. Mas, a base, a matéria prima dos textos jornalísticos era, na maior parte dos casos, constituída pelas informações veiculadas pela própria imprensa burguesa que se pretendia combater com uma imprensa alternativa. $\mathrm{E}$ isso comprometia a qualidade, o nível, o alcance de boa parte do material da imprensa alternativa (Abramo, 1988: 16).

Todavia, as considerações de Abramo não podem ser estendidas quando se tem em mente a parte doutrinária do Brasil, Urgente. É o que se percebe, por exemplo, nas Reportagens Históricas, no ABC Social Cristão e em outras séries de reportagens divulgadas pelo hebdomadário. Esses temas não tinham a intenção de contrapor a divulgação da Doutrina Social da Igreja a outros jornais da época, como a Folha de S. Paulo e O Estado de São Paulo (Estadão); raras foram as ocasiões em que esses jornais dedicaram páginas a assuntos do interesse da Igreja. Os objetivos desses escritos ultrapassavam o campo das lutas simbólicas pelo monopólio legítimo da informação política.

Jornal de inspiração cristã, durante sua curta existência, de 17 de março de 1963 a 28 de março de 1964, Brasil, Urgente tentou inovar o modo de informar seus leitores acerca dos principais fatos do país e da renovação teológica da Igreja Católica, suscitada muito antes do Concílio Vaticano II (1962-1965), convocado por João XXIII. O esforço do semanário para legitimar sua prática ante os leitores - favoráveis ou não à sua posição progressista - foi uma constante seguida ao longo de sua existência, encerrada com o golpe de 1964. Para tanto, o jornal lançou mão de recursos que visavam a educar e formar seu público leitor, entre os quais podem ser destacadas reportagens sobre temas como a reforma agrária, as reformas de base e a posição dos cristãos sobre a realidade social. As Cartilhas ${ }^{5}$ nome dado a esses registros - tiveram o intuito de preparar e, principalmente, educar os leitores para uma maior adesão ao projeto de reformas sociais. Segundo Roberto Freire, articulista do semanário, o conteúdo das matérias publicadas no Brasil, Urgente "era o pensamento dos católicos que produziam o jornal sobre a realidade brasileira, mas o jornal Brasil, Urgente não era um jornal de divulgação da Igreja e do catolicismo" (Freire, 2002: 166).

A manutenção técnica do periódico era viabilizada pelo Conselho de Direção, formado por dez pessoas, ${ }^{6}$ entre as quais estavam os jornalistas Dorian Jorge Freire e Josimar Moreira de Mello, vindos do jornal Última Hora (1951-1970), fundado pelo jornalista Samuel Wainer. Ruy Cézar do Espírito San- 
to exercia a direção administrativa e Roberto Freire era, inicialmente, o diretor responsável. Todas as quintas-feiras, os grupos ligados ao jornal se reuniam para definir os assuntos que seriam as manchetes principais da edição seguinte. No sábado, os exemplares seguiam rumo às grandes capitais do país. A distribuição do semanário ficou por conta dos leitores convocados para esse serviço. ${ }^{7}$

Os recursos utilizados pelo jornal para fazer valer seu poder simbólico, enquanto porta-voz de uma ampla rede de movimentos em defesa da pessoa huma$n a$, eram variados e inconstantes. Como exemplo, podemos citar as seguintes seções intermitentes: O povo diz o que pensa, Debate, Depoimento da Semana e Sessão Diálogo. Embora, numa visão superficial, se possa articular essa inconstância ao ritmo alucinante da sucessão de fatos sociais do ano de 1963, ela reflete muito mais a multiplicidade de vozes que falavam pelo jornal. Destarte, seria unilateral considerar essa particularidade como resultante, unicamente, de influências externas. O depoimento de Frei Carlos lança luz a propósito dessa propriedade do hebdomadário. Ao ser questionado se o radicalismo do jornal era o da Ação Popular (AP) ou da Ordem Dominicana, o sacerdote enfatizou que:

há aí um encontro de várias correntes com uma unidade de marcha, de ação, mas com uma certa autonomia [...] nem é assim, um jornal que traduz a posição do esquerdismo da Ordem Dominicana, nem da AP, nem, assim, de um grupo de comunistas, nem de um grupo de sindicalistas, é uma resultante. Agora, de modo que o problema nosso, por exemplo, quando a gente fazia uma reunião - um congresso - ou quando a gente fazia, então, uma reunião de uma elite, de um grupo de elite para dirigir o jornal, a gente procurava atender tudo isso. $\mathrm{E} \mathrm{o}$ princípio de diálogo era esse (entrevista concedida ao autor em 7 de julho de 2006, p. 240).

O caráter instável das seções revela, por conseguinte, a proposta maior do semanário: o diálogo, cujo objetivo seria aglutinar os diferentes movimentos sociais, partidários da renovação e da revolução, reservando a cada um sua devida participação. Ainda segundo Frei Carlos,

o princípio de diálogo era esse de dizer: olha, no jornal tem esse projeto, nós todos estamos de acordo com isso; agora, você que é comunista, você vai chegar e discutir sobre esse projeto, você não me vai trazer idéia do Partido Comunista - que não me interessa. Eu sou católico, eu sou dominicano, eu não vou trazer aqui para você a posição dos dominicanos; eu vou trazer a posição sobre essa nossa coisa aí, que diz 


\section{Lucas Aparecido Costa}

como é que nós vamos discutir esse projeto, como é que vamos alargar esse projeto e fazer tema para esse projeto [...] Mas isso é interessante, você tem aí um encontro, uma força na linha do que nós encontramos em Karl Marx. Então, é isso aí que é o problema que, para mim, foi muito rico: um esforço de um diálogo que não reduzisse, que não fosse redutivo em relação às várias posições. Quer dizer, no fundo são dez posições, então três prevalecem, e sete não? Nós vamos ver que as dez posições podem chegar e se apresentar, e quando, por exemplo, numa tomada de posição uma ficou de lado, na próxima você vai - essa posição é mais intelectual -, bom, nós vamos fazer um número do jornal em que você vai entrar mais, etc. Então isso aí é uma questão de importância do diálogo, que às vezes o diálogo leva a um acordo [...] (entrevista concedida ao autor em 7 de julho de 2006, p. 256 e 257).

No dia 15 de fevereiro de 1963, dois meses antes da publicação de seu primeiro número, a Comissão Organizadora de Brasil, Urgente encaminhou aos titulares da sociedade anônima a primeira notificação referente aos trabalhos de elaboração do jornal. Nesse documento o comitê esquematizou suas propostas:

O JORNAL DO POVO será lançado em duas etapas. A primeira, que será efetivada a 17 de março, compreenderá a publicação de uma edição nacional, com absoluta penetração em todo o país, editada semanalmente, sob o título de "BRASIL, URGENTE - Um Jornal do Povo a Serviço da Justiça Social”. Em seguida, com a equipe devidamente estruturada e a maquinaria ajustada, partiremos para o grande diário, dirigido especificamente a São Paulo, enquanto o nosso Frei Carlos Josaphat prepara os artigos que assinará em "BRASIL, URGENTE". 8

A segunda etapa aludida pela Comissão não foi levada a cabo. Durante sua breve história, tanto na cidade de São Paulo quanto nos demais municípios do interior do estado, e em outras regiões brasileiras, o jornal continuou a circular semanalmente. Maria Olympia França, que por algum tempo fez parte da equipe administrativa de Brasil, Urgente, afirmou que o semanário "figurava nas bancas de jornais do Brasil e em vários outros países do mundo" (França, 2002: 435). A intenção era, de início, ampliar o jornal e transformá-lo, de acordo com o sucesso adquirido, em diário. Frei Carlos Josaphat desejava lançar, concomitantemente à circulação do diário, uma publicação mais doutrinal, 
cujo título seria "Cadernos de Brasil, Urgente" (Meneses, Cunha Jr., Jensen e Tenório, 2002: 482).

A história das origens do semanário, bem como de sua luta, posição ideológica e princípios de atuação foi apresentada em seu primeiro editorial (sem título). O financiamento inicial de Brasil, Urgente partiu da venda de cotas e ações para simpatizantes, perfazendo um total de oito mil acionistas:

Este jornal não nasceu de interesses econômicos. Não surge bafejado por grupos políticos e financeiros. Nem brota de beneplácito de trustes, nacionais ou internacionais. Começa a existir porque oito mil acionistas, brasileiros de todas as camadas sociais, particularmente trabalhadores e homens da classe média, estão convencidos de que se faz necessário um "Fornal livre, a serviço exclusivamente da verdade e da justiça social”. Liberdade. Verdade [...]" (Brasil, Urgente, 17/3/1963, grifo do jornal).

No mesmo editorial, Brasil, Urgente deixava claras para o leitor suas posições: a moral - jornal de inspiração cristã, e não órgão oficial da hierarquia católica - e a política - veículo de total apoio ao programa de reformas de base. Sua proposta foi alicerçada em três linhas mestras: $1^{\text {a }}$ ) Usar a liberdade para dizer a verdade, "a verdade sobre os homens. Sobre as instituições. Sobre a conjuntura nacional e internacional" (Brasil, Urgente, 17/3/1963); $2^{\mathrm{a}}$ ) Muito mais do que informar os leitores, opinar sobre os acontecimentos relevantes para a sociedade brasileira, em suas diversas esferas; no entanto, com vistas a estabelecer uma total imparcialidade na apresentação dos fatos, ${ }^{9}$ o semanário se atribuía a tarefa de renunciar aos mitos da direita e da esquerda:

Por que nos irmanar aos que imaginam ou apregoam quer infernos quer paraísos no lado do Oriente ou do Ocidente? [...] procuraremos levar ao conhecimento dos leitores os dados, os números e os fatos que eles têm deveras vontade e necessidade de saber. Quais as reais condições de trabalho e qual o nível de vida do Nordeste brasileiro, o que vem a ser a reforma agrária de Fidel Castro, o que tem realizado a Aliança para o Progresso, qual a originalidade do socialismo iugoslavo ou qual o significado do cooperativismo nos países escandinavos. Honestas reportagens deste tipo não hão de faltar em nenhum de nossos números. Se isso é ser esquerda, somos esquerda. (Brasil, Urgente, 17/3/1963, grifo do jornal). ${ }^{10}$ 


\section{Lucas Aparecido Costa}

$3^{\text {a) }}$ Lutar pela justiça social, conforme o sentido atribuído pelo ensino magisterial de João XXIII, sintetizado em suas encíclicas sociais. Sobre este terceiro ponto, o editorial enfatizava que a simples veiculação do ensino social da Igreja não bastaria; deveria ser a doutrina confrontada e aplicada aos fatos sociais: "daí a necessidade da análise destemida e profunda do atual processo de desenvolvimento brasileiro, em seu conjunto e em suas peculiaridades, em suas características regionais, bem como em suas implicações continentais e internacionais" (Brasil, Urgente, 17/3/1963).

Tendo como objetivo ampliar o campo de atuação e consolidar sua presença junto aos meios católicos, Brasil, Urgente valeu-se do apoio moral do cardeal arcebispo de São Paulo, Dom Carlos Carmelo de Vasconcellos Motta. Para tanto, o semanário divulgou, em sua segunda edição, o discurso proferido pelo cardeal a propósito da festa de lançamento do hebdomadário: "Devemos alargar os espaços da verdade e dilatar os espaços da caridade, abrindo os caminhos da justiça que conduzem à fraternidade" (Brasil, Urgente, 24/3/1963).

Em outra edição, o cardeal confrontou a situação brasileira com as circunstâncias da França à época da Revolução de 1789; ao Brasil era possível ainda, diferentemente da ocasião vivida por aquele país, uma "solução dentro da crise", em que se poderiam combinar mudanças sem a necessidade de recorrer a uma insurreição. O cardeal deixou entrever, em seu discurso, as propostas da terceira via, que animavam um grande número de católicos. Ressaltou a necessidade de um remédio para a situação nacional, vista por ele como febril, "anunciando uma enfermidade grave".

Dom Carlos Motta aconselhava prudência quanto ao tipo de remédio a ser empregado - haja vista o perigo de se cair em extremismos -, o qual, "dado em 'dose cavalar', poderia matar o doente" (Brasil, Urgente, 21/4/1963). Sendo assim, o clérigo ressaltava a importância do jornal no processo de conscientização da população a respeito da crise social pela qual passava o Brasil. Ao fazer uso de sua condição, enquanto membro da fração dominante do campo religioso, o cardeal orientou os fiéis ao estudo e à difusão da Doutrina Social da Igreja, atualizada por João XXIII em suas encíclicas sociais; lembrou-se das grandes inovações trazidas por essas cartas apostólicas, sobretudo a Pacem in Terris, primeiro documento endereçado por um pontífice a todos os homens, independentemente de serem ou não católicos.

Alceu Amoroso Lima, homem de elevado capital econômico e especialmente cultural e político, também se posicionou a respeito do lançamento do semanário. Em seu depoimento, elogiou as propostas do Brasil, Urgente anunciadas em seu primeiro editorial. Expressando sua posição, onde se pode visualizar a adesão explícita ao programa conhecido por terceira via, o escritor enfatizou que, num momento marcado pelo crescimento dos antagonismos entre direita $\mathrm{e}$ 
esquerda, o trabalho de um veículo de comunicação, com pretensões genuinamente cristãs deveria se dar no sentido de atenuar essa situação. Para levar a cabo uma reforma profunda dos homens e das instituições, fez recordar as exigências indicadas por Pio XI (1922-1939) em sua encíclica Quadragesimo Anno (1931). Não obstante o elogio às prerrogativas traçadas pelo jornal, Amoroso Lima observou não ser prudente ao hebdomadário deixar-se identificar como mensageiro da esquerda. Assim se posicionou o escritor:

como diz claramente depois de enunciar alguns dos seus propósitos: "se isso é de esquerda, somos esquerda". Ora, isso não é esquerda nem direita. É a libertação, a verdade, a justiça, com princípios conjugados e trazidos para o terreno dos fatos concretos, na crítica deveras construtiva e justa à nossa política e à nossa economia dominantes, nos meios imobilistas ou reacionários (Brasil, Urgente, 21/04/1963).

Amoroso Lima ajuizou, ao mesmo tempo, a proposta de democracia apresentada pelo semanário em seu primeiro editorial. $\mathrm{O}$ mais urgente para aquele arco de tempo, muito mais do que optar por democracia ou totalitarismo, seria, nas palavras do escritor, definir de forma lúcida e clara "o que se entende por democracia autêntica e realmente antitotalitária" (Folha de São Paulo apud Brasil, Urgente, 7/4/1963). A concepção cristã desse sistema de governo, endossando uma vez mais as propostas da terceira via, deveria ser norteada pela prática solidarista cristã, cujo vértice apontava para uma reforma dos costumes e das instituições. ${ }^{11}$

Brasil, Urgente reafirmou sua linha editorial em seu vigésimo quinto número, de setembro de 1963, intitulado "Reafirmação de Princípios". O hebdomadário fez um esboço da sua caminhada durante os seis primeiros meses de existência; apresentou-se como exemplo único de imprensa realmente independente dos poderes econômicos; endossou sua fidelidade à doutrina social cristã, especialmente às diretrizes pastorais emanadas da Mater et Magistra e da Pacem in Terris:

Enquanto a maior parte da imprensa silenciava sobre o IBAD e o IPES ou minimizava os efeitos de sua atuação, apontamos ao Brasil as gravíssimas consequências de uma atuação ilegítima e antidemocrática [...] Dissemos que a democracia só se sustenta legitimamente quando seu poder for legitimamente constituído e que todo compromisso com forças econômicas é necessariamente nocivo aos interesses da coletividade e do bem comum. Defendemos a Petrobrás, Fronape, Sudene, 


\section{Lucas Aparecido Costa}

siderúrgicas [...] Batemo-nos por reformas de base, humanas e cristãs: constitucional, agrária, urbana, bancária, empresarial, universitária, eleitoral [...] Defendemos a doutrina social cristã, lutando tenazmente para a compreensão real e a aplicação prática e dinâmica das encíclicas sociais e notadamente da "Mater et Magistra" e "Pacem in Terris" [...] Ferimos interesses de pessoas e grupos. Daí sermos objeto da ira dos poderosos que não aceitam a existência de um jornal incômodo, indócil e indiferente às sugestões de suas torpes tentativas de suborno. A reação contra nós desencadeada é furiosa e visa tão somente liquidar uma das poucas vozes livres e autênticas da imprensa no Brasil (Brasil, Urgente, $1 / 9 / 1963)$.

Reflexo da convivência desses cristãos em meio aos comunistas, e também do receio de serem confundidos ambos os grupos, Brasil, Urgente destacou estar pautada sua ação "rigorosamente pelos princípios cristãos inscritos nos Evangelhos" (Brasil, Urgente, 1/9/1963). Ao mesmo tempo, a postura mais avançada do hebdomadário e a liberdade considerável de circulação de idéias - uma das suas características fortes - desautorizavam-no a se posicionar como imprensa católica, como era o caso do jornal O São Paulo, da Arquidiocese Metropolitana. Destarte, Brasil, Urgente não pretendia ser porta-voz da hierarquia eclesiástica.

Em uma análise rápida, o editorial em questão representa o perfil da Igreja socialmente engajada, caracterizada por uma volta às origens do cristianismo. Embora tenha sido este o atributo mais destacado pelo semanário, procuramos ir além das "aparências". No mesmo editorial, embora se tenha feito a defesa, em termos evangélicos, de uma situação mais justa e humana, percebe-se a marcha rumo à futura Igreja Popular. Não se abandona a fé no Evangelho, porém a práxis social reorienta a prática de fé e a experiência eclesial, "o que leva a uma transformação profunda e radical da expressão da fé e das formas concretas de construção da Igreja. Vive-se, pois, uma convergência entre a radicalidade do engajamento político e a radicalidade da fé" (Richard, 1982: 221-222). Supera-se então, e é exatamente esta característica que torna a prática eclesial de Brasil, Urgente mais avançada, "toda possibilidade de 'clericalismo de esquerda', ou toda a possibilidade de 'messianismo político-religioso', ou toda reedição, agora de 'esquerda', de uma 'terceira via política', ou 'social-cristianismo'" (Richard, 1982: 221-222). ${ }^{12}$

No editorial ora analisado, temos como resultado mais direto da manifestação da fé reorientada pela práxis social a alegação de uma forma específica de Igreja; dito de outro modo: o pensamento que pretende justificar uma Igreja a serviço dos pobres: "Defendemos e continuaremos a defender a Igreja, o clero e 
sua hierarquia, toda vez que eles, como resultado de sua ação em favor dos humildes e da verdade, forem vítimas da grande imprensa e de seus patrocinadores" (Brasil, Urgente, 1/9/1963).

A defesa de um novo perfil de Igreja é novamente enfatizada no editorial de número 40, Uma vitoria aparente, de dezembro de 1963. A condenação foi direcionada às autoridades eclesiásticas e à frouxidão da Ordem Dominicana no caso do exílio, em novembro daquele ano, de Frei Carlos Josaphat. O julgamento dos fatos referentes à saída de Josaphat ultrapassava uma visão solidarista-cristã:

O poder econômico dobrou de fato as autoridades vaticanas, tão sensíveis ao fascínio do poder político e aos encantos das forças do dinheiro. Contou de fato para o êxito de sua empreitada, com a frouxidão surpreendente da Ordem Dominicana, tão valente na defesa de teses e tão medrosa no processo de luta. Conseguiu realmente afastar do Brasil, em hora tão grave e decisiva para os destinos nacionais, um líder da envergadura de Frei Carlos Josaphat, autêntico apostolo do cristianismo verdadeiro, fundador e impulsionador e orientador de BRASIL, URGENTE - jornal e movimento [...] Frei Carlos Josaphat parte quando a terra brasileira que semeou palmo a palmo começa a apresentar seus primeiros frutos [...] $\mathrm{O}$ dinheiro da reação não destrói realidades [...] Absolutamente tranquilo, pode esperar o julgamento de Deus, do povo e da história. Acontecerá o mesmo com os que tornaram possível a expulsão do padre brasileiro? Terão cumprido os seus deveres para com Deus, a Igreja e a verdade, as autoridades vaticanas que cederam à voz do poder econômico? Terão cumprido seu dever para com Deus, a Igreja e a Ordem Dominicana, o mestre-geral dominicano em Roma ou provincial daquela Ordem no Brasil? Conhecerão eles o conforto, a bênção e graça de um sono tranquilo? De uma consciência pacificada? Como enfrentarão a voz da história? Como surgirão no julgamento da posteridade? A subserviência nunca foi o melhor rumo para alcançar a história ou a tranquilidade de consciência. BRASIL, URGENTE está tranquilo e pode mandar ao povo do Brasil uma mensagem de fé. Os rumos traçados por Frei Carlos Josaphat não serão alterados. Este jornal, que não cedeu e não cederá à expressão do poder econômico, não se acovardará diante do farisaísmo e da covardia. Continuaremos no mesmo caminho. Um jornal do povo a serviço da justiça social. Um jornal comprometido apenas com a verdade. Um jornal inserido na luta de todo o povo brasileiro, pela libertação da pátria e por um cristianismo mais autêntico e menos demissionário (Brasil, Urgente, 29/12/1963, grifo nosso). ${ }^{13}$ 


\section{Lucas Aparecido Costa}

Para ilustrar melhor essas posições, contamos uma vez mais com o depoimento de Frei Carlos Josaphat sobre aquele período. Segundo o sacerdote, os padres que atuavam na linha das reformas sociais já tinham em mente um propósito de mobilização incompreensível mesmo para bispos como Dom Hélder Câmara. Para Josaphat, a ocasião exigia um movimento "não em nome do cristianismo, mas em nome do povo, com uma inspiração evangélica, inspiração cristã, [capaz de] mobilizar para poder fazer a reforma social-econômica e político-cultural" (Meneses, Cunha Jr., Jensen e Tenório, 2002: 456). A incompreensão ou mais acertadamente - a cautela dos bispos a respeito das pretensões de Josaphat e dos demais padres sinaliza uma posição mais avançada, dentro da prática eclesial desses religiosos, das frações dominadas do campo religioso, na qual já se visualizavam, ainda timidamente, as características da Igreja politicamente engajada ou Igreja Popular. O centro do movimento indicado por Josaphat deveria ser o homem; era o ser humano igualmente, do lado dos comunistas, o cerne da questãoreservadas as profundas diferenças de acepção do homem para ambos os sistemas de pensamento.

As evidências de uma prática politicamente engajada, nos planos de Josaphat e, de um modo geral, em Brasil, Urgente tornaram-se ainda mais presentes quando o frei criticou o perfil dos partidos confessionais do período. Na sua visão, um partido político assim caracterizado não abandonaria jamais a linha doutrinária a que se prendia. Também os bispos eram cautelosos nesse sentido. Sobre a questão, afirma Josaphat:

Havia a Democracia Cristã aqui no Brasil, na América Latina, uma grande força no Chile. Mas o problema da Democracia Cristã é aceitar o que aí está e botar um pouco de água benta na coisa, falando uma linguagem cristã e dando alguns privilégios para a Igreja, o que nós consideramos como uma verdadeira blasfêmia ao nome cristão. O partido confessional quer prerrogativas para nós, cristãos, e conservar o sistema econômico que aí está: é antievangélico (Meneses, Cunha Jr., Jensen e Tenório, 2002: 456).

Em síntese, a dura crítica que vinha sendo feita por Josaphat, muito além de ter extrapolado a modernidade pretendida pela Igreja Católica, suplantou a fronteira estabelecida pelo capitalismo dependente. Desde a publicação do seu livro Evangelho e revolução social, ${ }^{14} \mathrm{em} 1962$, o frei passou a ser alvo de constantes ataques. O livro fazia uma crítica ao imobilismo social dos cristãos; alertava para a imprudência que seria comparar o comunismo com um materialismo grosseiro; Josaphat indagava ainda se o marxismo não teria razão em afirmar a evasão vivida e pregada pela prática social cristã (Josaphat, 1962). 
A censura - vinda da hierarquia eclesiástica - ao conteúdo das matérias noticiadas pelo semanário já se havia tornado visível três meses antes da partida do frei, quando se divulgou o artigo Desfazendo equívocos, de autoria de Dom Motta. O cardeal havia confirmado em nota a declaração da CNBB, cujo presidente na ocasião era Dom Jaime de Barros Câmara. A carta, publicada pelo jornal em seu $28^{\circ}$ número, determinava o seguinte:

As notas oficiais publicadas pela Redação de Brasil, Urgente e a Conferência Nacional dos Bispos do Brasil bastam para desfazer os equívocos, deixando bem claro, para a gente de boa fé, que esse jornal não é órgão de Imprensa Católica, isto é, não é da propriedade nem da responsabilidade da Igreja. É jornal de iniciativa particular e de apostolado de católicos dos leigos. São Paulo, 18.8.1963. C. cardeal Motta, Arceb. Metrop (Brasil, Urgente, 22/9/1963).

Dom Carlos Motta, não obstante seu apoio à iniciativa do semanário, confirmou a declaração da CNBB. Para Josaphat, aquela afirmação, no contexto em que foi publicada, afetou negativamente o trabalho do apostolado leigo que apoiava a linha editorial de Brasil, Urgente, pois "a declaração era lida nas igrejas. Portanto, isso significava dizer: 'Você não ligue para esse jornal, não é jornal de igreja, é jornal de um grupo de leigos etc' - o que de fato valia como uma retirada de apoio" (Meneses, Cunha Jr., Jensen e Tenório, 2002: 495). ${ }^{15}$

No que se refere ao estudo das vozes variadas que falavam através do jornal, assume importância fundamental a inovação doutrinal inaugurada pela encíclica Pacem in Terris, que passou a distinguir teorias e movimentos sociais suscitados por estas; o que torna muito significativas a evolução das críticas da hierarquia em relação ao socialismo e também da prática politicamente engajada do semanário Brasil, Urgente. Os princípios anunciados nos documentos oficiais, de Pio XI a João XXIII, em relação a esse sistema mantiveram uma constante: a refutação do socialismo independentemente de sua aproximação com alguns princípios da doutrina cristã. No entanto, como havíamos afirmado, João XXIII, na Pacem in Terris, diferencia teoria de movimentos práticos, estabelecendo o seguinte:

Além disso, cumpre não identificar falsas ideias filosóficas sobre a natureza, a origem e o fim do universo e do homem, como movimentos históricos de finalidade econômica, social, cultural e política, embora tais movimentos encontrem nessas ideias filosóficas a sua origem de inspiração (João XXIII, 1963: 617). 


\section{Lucas Aparecido Costa}

Na era do diálogo com a modernidade, iniciada com João XXIII, já não fazia mais sentido uma cruzada contra formas de pensamento opostas à filosofia católica da história. Logo, a maneira - idealizada pelo pontífice e por uma parcela de católicos - de vencer o inimigo seria levar a mensagem cristã em toda sua radicalidade. Nesse sentido, os católicos, ambicionando fazer pelo povo o que o comunismo ambicionava perpetrar, estavam situados, ainda, numa prática socialmente engajada, pois justificavam sua luta social em nome do cristianismo com vistas a submeter os valores modernos à concepção cristã de pessoa humana. Após a fé ter começado a ser condicionada pela práxis social e pela valorização do homem, o caminho dos católicos se desviou para o socialismo e o comunismo de vertente marxista.

Aos cristãos não haveria possibilidades de aceitação (caso continuassem tendo por base o solidarismo cristão) da teoria e da organização política da práxis; logo, uma posição mais avançada entre os fiéis assumiu, como forma de interpretação da realidade, o socialismo de filiação marxista. Há que ressaltar a forma grosseira e ao mesmo tempo idealista dessas primeiras interpretações muito mais próximas do hegelianismo. ${ }^{16}$

No encontro das radicalidades, exigidas por uma releitura grosso modo marxista da prática da fé, os textos adquirem outro sentido. A união entre política efé - reservada a autonomia dos campos e sem perder de vista o panorama histórico-social que possibilitou o diálogo entre cristianismo e marxismo - encontrou nos leigos das ramificações especializadas da Ação Católica, outrora convocados por Dom Sebastião Leme para serem a retaguarda do projeto de recristianização da sociedade, o elo entre opção evangélica e opção política. Não pretendemos com isso afirmar a marxização do discurso dos leigos católicos, mas ressaltar a consciência dos fiéis sobre a inviabilidade do uso de outro referencial teórico para entender os processos geradores da miséria social que não fosse o marxismo.

\section{Considerações finais}

Considerando a situação histórica do início da década de 1960, nosso artigo se amparou em uma fonte raríssima no estudo da prática engajada dos cristãos - o semanário Brasil, Urgente. Por meio da análise pontual de alguns editoriais, foi possível entrar em contato com uma fonte documental resultante (indiretamente) da valorização do leigo (como sujeito ativo) pela Igreja e, também, acessar a discussão pertinente às diversas formas de extinguir os processos que desumanizavam o mundo, fazendo dele uma desordem estabelecida. A partir dos editoriais consultados, percebemos que as tendências, no jornal, variavam desde uma postura defensora da terceira via até a opção da fé reorientada pela racionalidade da práxis social; logo, o pluralismo de idéias de Brasil, Urgente - cen- 
trado no conceito de libertação do homem pela verdade - aglutinou, ao mesmo tempo, concepções diferenciadas de Igreja.

Dito de outro modo, as críticas de Brasil, Urgente - endereçadas à sociedade, à prática inerte de um cristianismo individualista e ao ateísmo materialista do capitalismo - seguiam um movimento pendular: iam desde uma censura feita em termos puramente morais, consistente em defender a mesma ideia de modernidade das frações dominantes da Igreja, até uma admoestação, em cujo núcleo se percebia uma fé reorientada pela racionalidade da práxis, aberta a um determinado tipo de marxismo, adotado pouco a pouco como referencial mais eficaz para entender/transformar o mundo e a subjetividade moderna.

Todo o contexto histórico, somado às lutas internas ao campo religioso $\mathrm{e}$, principalmente, os movimentos de valorização do homem como pessoa humana, possibilitaram a aproximação (para fins práticos) não somente entre cristãos e marxistas, mas, de um modo geral, de todos os que propunham, com matizes diferenciados, formas mais humanas de sociedade. Assim, o encontro, debate ou diálogo (reportando ao nosso estudo específico) teve como fator preponderante a atmosfera - posterior à Segunda Grande Guerra - de valorização do homem.

Notas

1. Esse conceito representa para a Igreja Católica a segunda pessoa de Cristo - sua face humana. Essa concepção de ser humano, cuja origem remonta à filosofia helenista, foi aprofundada pela matriz romana e em seguida pelo cristianismo, quando a Igreja procurou debater a respeito da Santíssima Trindade. A pessoa humana é o núcleo a partir do qual a instituição eclesiástica orienta todo o seu ensino social e avalia as diferentes realidades temporais. Com base nesse preceito de ser humano, a Igreja reprovou dois sistemas de ideias diametralmente opostos - capitalismo, de um lado, e, do outro, o comunismo: "é exatamente em nome da pessoa humana que se condena o 'materialismo capitalista', na medida em que celebra a cobiça e transforma o homem em coisa, ou o 'materialismo ateu dos comunistas', que suprime as liberdades humanas" (Mello e Novais, 1998: 610).

2. Lançamos mão, ao longo do artigo, de vários conceitos vindos da teoria da sociologia da prática de Pierre Bourdieu, como por exemplo os de capital, campo, frações dominadas e dominantes. Nas referências bibliográficas citamos as obras desse sociólogo que tratam justamente dos termos em destaque.

3. Entendemos a modernidade pretendida pela Igreja Católica como aquela baseada na revitalização da fé e no uso social dos bens terrenos, em contraponto, portanto, à modernidade abstrata e individualista que tinha como base tão-somente a vitalidade 
do capital. Destarte, uma parte da Igreja, que procurou firmar diálogo com determinados pontos da modernidade, não buscou apoio, para analisar o mundo que a cercava, no socialismo. Essa observação não pode, porém, ser estendida ao laicato que aderiu à leitura marxista da sociedade - façamos referência, nesse sentido, aos católicos do movimento e semanário Brasil, Urgente. Nesse sentido, compreendemos o socialismo de filiação marxista como um valor não utilitário da modernidade, que problematizava a própria modernidade - referência seja feita, sobretudo, ao capitalismo.

4. O teólogo Pablo Richard (1982) separa as práticas da Igreja Católica posteriores aos anos de 1960 em duas categorias. Segundo o autor, a Igreja socialmente engajada tem na mensagem evangélica a justificativa para sua ação sociopolítica; o conceito ilustra as posições da Esquerda Católica dos anos de 1960, onde não se percebe claramente uma opção política pelo socialismo. A Igreja politicamente engajada faz o caminho inverso: o agir antecede a reflexão evangélica, a práxis redefine a fé e a interpretação que se tinha acerca das Sagradas Escrituras; essa forma ou tipo de Igreja adere declaradamente a um projeto político socialista e se consolida ao longo da década de 1970. Para nós, esses dois tipos de práticas eclesiais não existiram separadamente, de modo que podem ser contempladas em um mesmo grupo ou movimento católico.

5. As Cartilhas foram reportagens especiais cujo objetivo era informar e orientar a posição dos leitores sobre as reformas de base. Ao longo de sua existência, Brasil, Urgente elaborou três cartilhas, vinculadas a temáticas diferentes: Cartilha do Desenvolvimento $\left(\mathrm{n}^{\circ} 15 \mathrm{a} \mathrm{n}^{\circ} 21\right)$, Cartilha da Reforma $\left(\mathrm{n}^{\circ} 10\right.$ a n $\left.^{\circ} 14\right)$ e $A B C$ Social Cristão $\left(\mathrm{n}^{\circ} 32\right.$ a n⿳38). Esta última Cartilha pode ser considerada a continuidade de uma série de reportagens históricas, divulgadas pelo jornal em suas edições de número 25 a 31.

6. O Conselho de Direção do Brasil, Urgente, em seu primeiro número, estava assim composto: Fr. Carlos Josaphat; Ruy Cézar do Espírito Santo; Roberto Freire; Alfredo C. B. Gandolfo; José Raul B. Carneiro; Gilberto Moreira, Dorian Jorge Freire, Josimar Moreira; Fausto Figueira de Mello e Maria Olímpia França. Desses membros, apenas Ruy Cézar e Roberto Freire acompanharam o jornal até a edição de seu último número, em 28 de março de 1964.

7. Essa colaboração não era remunerada. A equipe da direção, sempre que necessário, fazia uma convocação para que todos os brasileiros sedentos de justiça auxiliassem a sobrevivência do jornal prestando serviços voluntários, fosse com assinaturas, com reportagens ou mesmo na distribuição.

8. Esta informação consta em uma folha avulsa localizada em meio às edições do jornal, guardadas em uma caixa na Biblioteca de Pesquisas Religiosas (São Paulo). Em nossa dissertação de mestrado incluímos esse folheto na parte dos Anexos (Costa, 2006: 256).

9. Embora o jornal tivesse como escopo "uma total imparcialidade na apresentação dos fatos", sabemos que os textos, assim como as fontes orais, estão carregados de subjetividade, cujo conteúdo se vincula ao contexto histórico e social em que foram produzidos.

10. No sentido de não optar por Ocidente ou Oriente, o jornal esteve em plena conformidade com os propósitos da Igreja esboçados na Mater et Magistra, que, segundo Alceu Amoroso Lima, criticava apenas a civilização moderna, identificada com o liberalismo do capitalismo e o totalitarismo do coletivismo. 
11. Antônio Sagrado Bogaz aborda detalhadamente os postulados fundamentais de Jacques Maritain. Como uma das respostas maritainianas para nosso tempo, a terceira via "se refere, sobretudo, ao equilíbrio, na educação, na forma de governo, na filosofia e na teologia, da relação entre a realização pessoal e a edificação comunitária, no confronto equilibrado entre o individual e o coletivo, como possibilidade de assumir o ser humano em sua 'pessoalidade' e, como expressão deste conceito, as relações com as pessoas, com os grupos sociais e com o cosmos, perpassando pela ação da graça divina na sua existência" (Bogaz, 2003: 351). Não se limita a terceira via "à competição entre os poderes das potências mundiais, pois sua proposta é mais profunda e mais abrangente" (Bogaz, 2003: 351), pois valoriza as dimensões histórica e transcendental do homem.

12. Para uma compreensão mais detalhada sobre a influência do pensamento marxista no jornal Brasil, Urgente, ver Costa (2006).

13. A informação sobre a saída de Josaphat foi noticiada em novembro de 1963, poucos dias antes de sua retirada definitiva do Brasil. O editorial - que tinha por título o nome do frei - enfatizou que a linha de atuação do semanário continuaria sendo a mesma, o que de fato comprovamos, pois sua ação continuou a ser pautada pelos dois modos de prática eclesial: a socialmente e a politicamente engajada. No editorial subsequente, os diretores pediram desculpas pelas críticas feitas à Igreja Católica e à Ordem Dominicana. $\mathrm{O}$ discurso, nesse editorial, totalmente fora dos padrões combativos do Brasil, Urgente, admitia ter o jornal cometido excessos gravíssimos contra a Igreja Católica e reafirmava sua subserviência a essa instituição e sua convicção cristã. Sobre o assunto confira: Brasil, Urgente, $\mathrm{n}^{\circ} 41,1963, \mathrm{p} .2$.

14. Frei Carlos Josaphat, a propósito de Brasil, Urgente, informa que "O ponto de partida, e até um pouco o critério de partida, era o meu livro Evangelho e revolução social. Não 'reforma social', mas reforma radical e, portanto revolução. As grandes linhas eram essas" (Meneses, Cunha Jr., Jensen e Tenório, 2002: 481).

15. O início desse episódio envolvendo a CNBB e Brasil, Urgente se deu quando o humorista Arapuã, no primeiro número do jornal, escreveu: "Eis, finalmente, o 'jornal dos padres'. Claro - o jornal dos padres. Ou vocês acham que brasileiro ia deixar passar mais esta oportunidade de batizar, a seu modo, as coisas e as instituições? Jornal dos padres. E, como, desde os tempos de Pero Vaz Caminha (o primeiro sujeito que escreveu neste País, exigindo 'rigoroso inquérito' para ver se havia e onde estava o ouro), se diz que 'jornalismo é sacerdócio', nada melhor para um jornalista que o jornal dos padres" (Brasil, Urgente, 17/3/1963). Esse episódio revela que a linha de ação do semanário estava orientada, inicialmente, pela modernidade pretendida pela Igreja Católica.

16. Sobre este ponto, ressaltamos a influência exercida pelo jesuíta mineiro Henrique de Lima Vaz, falecido em 1998. A mediação filosófica aplicada à realidade brasileira, devedora do esforço de Lima Vaz, foi muito forte nos meios internos da JUC. Deve ser lembrado que os jucistas batalharam, com Frei Carlos Josaphat, por uma imprensa independente; assim, muitas das posições avançadas do semanário Brasil, Urgente tiveram como ponto de partida os debates que já vinham sendo travados entre os universitários católicos. 


\section{Referências bibliográficas}

ABRAMO, Perseu. Imprensa alternativa: alcance e limites. Tempo e Presença, São Paulo, n. 233, p. 15-16, 1988.

BEOZZO, José Oscar. A Igreja no Brasil: de João XXIII a João Paulo II, de Medellín a Santo Domingo. Petrópolis: Vozes, 1993.

BOTAS, Paulo César Loureiro. A Bênção de Abril - "Brasil, Urgente": memória e engajamento católico no Brasil 1963-64. Petrópolis: Vozes, 1983.

BOURDIEU, Pierre. A economia das trocas simbólicas. São Paulo: Perspectiva, 1974.

- Questões de sociologia. Rio de Janeiro: Marco Zero, 1983.

O poder simbólico. Rio de Janeiro: Bertrand do Brasil, 2003.

BRASIL, URGENTE: um jornal do povo a serviço da Justiça Social. São Paulo: Veritas, 1963-1964. Semanal.

BRASIL, URGENTE: Entrevista com Frei Carlos Josaphat. In: BETTO, Frei; MENESES, Adélia Bezerra de \& JENSEN, Thomas (orgs). Utopia urgente: escritos em homenagem a frei Carlos Josaphat nos seus 80 anos. São Paulo: EDUC/Casa Amarela, 2002. p. 461-521.

CARDONNEL, Jean (org.). Socialismo e cristianismo. Rio de Janeiro: Paz e Terra.

COSTA, Lucas Aparecido. A esquerdização do catolicismo no Brasil: uma tentativa de modernidade nas práticas sociais da Igreja para o povo (1961-1964). Dissertação (Mestrado em História), Faculdade de História, Direito e Serviço Social, Universidade Estadual Paulista "Júlio de Mesquita Filho", Franca, 2006.
FERREIRA, M. M. \& AMADO (orgs). Usos E abusos da História Oral. Rio de Janeiro: Fundação Getúlio Vargas, 1996.

FIGUEIREDO, Argelina Cheibub. Democracia ou reformas? Alternativas à crise política: 1961-1964. São Paulo: Paz e Terra, 1993.

FRANÇA, Maria Olympia A. F. Uma urgência estancada. In: BETTO, Frei; MENESES, Adélia Bezerra de \& JENSEN, Thomaz (orgs). Utopia urgente: escritos em homenagem a frei Carlos Josaphat nos seus 80 anos. São Paulo: EDUC/Casa Amarela, 2002. p. 435-443.

FREIRE, Roberto. Eu é um outro: autobiografia de Roberto Freire. Salvador: Maianga, 2002.

GÓMEZ DE SOUZA, Luiz Alberto. $A$ FUC: os estudantes católicos e a política. Petrópolis: Vozes, 1984.

GORENDER, Jacob. Era inevitável o golpe de 64? In: TOLEDO, Caio Navarro de (org.). 1964: visões críticas do golpe: democracia e reformas no populismo. Campinas: Unicamp, 1997. p. 109-116.

KUCINSKI, Bernardo. Fornalistas e revolucionários: nos tempos da imprensa alternativa. São Paulo: Página Aberta, 1991.

LIMA, Alceu Amoroso. Entre imobilistas e acossados. Folha de São Paulo, São Paulo, 23 mai. 1963. $2^{\circ}$ Caderno, p. 2.

MARIANI, Ceci Baptista. Um apóstolo do evangelho social: entrevista com Frei Carlos Josaphat, OP. Espaços, São Paulo, v. 11, n. 2, p. 193-207, 2003.

MARTINS, FILHO, João Roberto. O movimento estudantil na conjuntura do golpe. In: TOLEDO, Caio Navarro de (org.). 1964: visões críticas do golpe: democracia $e$ 
reformas no populismo. Campinas: Unicamp, 1997. p. 75-81.

MELLO, João Manuel Cardoso de \& NOVAIS, Fernando A. Capitalismo tardio e sociabilidade moderna. In: SCHWARCZ, Lilia Moritz (org.). História da vida privada no Brasil. São Paulo: Companhia das Letras, 1998. 4. v.

MESQUITA, Luís José. As encíclicas sociais de foão XXIII. 2 ed. Rio de Janeiro: José Olympio, 1963. 2v.

MENESES, Adélia Bezerra de; CUNHA Jr., Melchíades; JENSEN, Thomaz \& TENÓRIO Waldeci. In: BETTO, Frei; MENESES, Adélia Bezerra de \& JENSEN, Thomaz. Utopia urgente: escritos em homenagem a frei Carlos Josaphat nos seus 80 anos. São Paulo: EDUC/Casa Amarela, 2002. p. 435-443.

NEVES, Lucília de Almeida. Trabalhadores na crise do populismo: utopia e reformismo. In: TOLEDO, Caio Navarro de (org.). 1964: visões críticas do golpe: democracia e reformas no populismo. Campinas: Unicamp, 1997. p. 55-74.

OLIVEIRA, Frei Carlos Josaphat Pinto de. Evangelho e revolução social. São Paulo: Livraria Duas Cidades, 1962.

RICHARD, Pablo. Morte das cristandades e nascimento da Igreja. São Paulo: Edições Paulinas, 1982.

THOMPSON, Paul. $A$ voz do passado. Rio de Janeiro: Paz e Terra, 1992.

\section{Resumo}

Com base na análise de editoriais do semanário Brasil, Urgente (1963-1964), o presente artigo ensaia algumas interpretações acerca do conteúdo veiculado por esse hebdomadário de inspiração cristã. Com o objetivo de se legitimar perante os movimentos sociais que também defendiam os direitos da pessoa humana, o jornal lançou mão de recursos variados e inconstantes. Desse modo, o pluralismo de ideias, presente nas páginas combativas de Brasil, Urgente, variava de uma postura defensora da terceira via até uma opção de fé reorientada pela racionalidade da práxis social.

Palavras-chave: Igreja Católica; Brasil, Urgente (1963-1964); doutrina social da Igreja; Igreja para o povo; Igreja Popular; tentativa católica de modernidade.

\section{Abstract}

Based on the analysis of certain editorials of the weekly publication Brazil, Urgent (1963-1964), this article attempts some interpretations concerning the content transmitted by that weekly paper of Christian inspiration. With the objective of being legitimated before the social movements that also defended the human being's rights, the newspaper used various and inconstant resources. Thus, the pluralism of ideas, which was present in the combative pages of Brazil, Urgent, varied from a defensive posture of the third path to an option of faith reoriented by the rationality of the social praxis. 
Key words: Catholic Church; Brazil, Urgent (1963-1964); social doctrine of the Church; Church for the people; Popular Church; catholic attempt of modernity.

\section{Résumé}

Basé sur l'analyse des points de vue de l'hébdomadaire Brésil, Urgent (1963-1964), cet article avance quelques interprétations sur le contenu publié par ce journal d'inspiration chrétienne. Dans le but de se légitimer devant les mouvements sociaux qui défendaient aussi les droits de la personne humaine, le journal a utilisé des ressources variées et inconstantes. Le pluralisme d'idées, présent dans les pages combatives de Brésil, Urgent, pouvait ainsi aller de la défense de la troisième voie jusqu'a une option de foi reorientée par la rationalité de la praxis sociale.

Mots-clés: Église Catholique; Brésil, Urgent (1963-1964); doctrine sociale de l'Église; Eglise pour le peuple; Église populaire; essai catholique de modernité. 